\title{
CHEMICAL, CLINICAL AND IMMUNOLOGICAL STUDIES ON THE PRODUCTS OF HUMAN PLASMA FRACTIONATION : XXXII. THE COAGULATION DEFECT IN HEMOPHILIA. AN IN VITRO AND IN VIVO COMPARISON OF NORMAL AND HEMOPHILIC WHOLE BLOOD, PLASMA AND DERIVED PLASMA PROTEIN FRACTIONS ${ }^{1}$
}

\author{
By JESSICA H. LEWIS, C. S. DAVIDSON, GEORGE R. MINOT, J. P. SOULIER, \\ H. J. TAGNON, AND F. H. L. TAYLOR \\ (From the Thorndike Memorial Laboratory, Second and Fourth Medical Services, Boston City \\ Hospital, and the Department of Medicine, Harvard Medical School, Boston)
}

(Received for publication July 10, 1946)

The clot promoting activity of normal blood or plasma on hemophilic blood has been known for many years. Weil (1) in 1905 first demonstrated that small transfusions of normal blood serum shortened the coagulation time of a hemophilic patient. Minot and Lee in 1912 (2) transfused normal blood into a hemophilic patient and attributed the prompt fall in coagulation time to the added normal platelets. In 1912 Addis (3) showed that normal serum had ability to shorten the hemophiliac's coagulation time both in vitro and in vivo. In 1924 Feissly (4) demonstrated that small transfusions of normal blood or plasma had an antihemophilic effect, but similar transfusions of hemophilic blood or plasma did not shorten the coagulation time of the recipient hemophiliac.

That the clot promoting ability of normal plasma was independent of the formed elements of the blood was shown by Patek and Stetson (5) and again confirmed by Patek and Taylor (6). The

1 This paper is No. 44 in the "Studies of Plasma Proteins" of the Harvard Medical School, Boston, Massachusetts, on products developed by the Department of Physical Chemistry from blood collected by the American Red Cross.

Some of the products of plasma fractionation used in this work were developed from blood collected for the American Red Cross by the Department of Physical Chemistry, Harvard Medical School, under contract recommended by the Committee on Medical Research between the Office of Scientific Research and Development and Harvard University.

The expenses of this investigation were defrayed in part by a Gift to Harvard University from Smith, Kline and French Laboratories, of Philadelphia, and in part by a grant given "in recognition of Dr. Francis W. Peabody's services to the Foundation" by the Ella Sachs Plotz Foundation. latter authors fractionated Berkefelded plasma, and found this antihemophilic activity to be present in the globulin fraction derived from normal plasma, but markedly reduced or absent in a similar fraction prepared from hemophilic plasma. In the same year Bendien and Van Creveld (7) independently achieved similar results from normal and hemophilic serums. Pavlovsky and Simonetti in 1944 (8), using the technique of Patek and Taylor, found identical hemophilic clot promoting activity in the globulin fractions of normal, thrombocytopenic and fibrinogenopenic plasmas, but in studying the globulin fractions from various hemophilic patients they found the antihemophilic activity variable and usually less marked than normal.

During the past 5 years new methods for fractionation of the plasma proteins have been developed by the Harvard Physical Chemistry Department (9). This paper presents an in vitro and in vivo comparison of these protein fractions derived from pooled normal and pooled hemophilic plasma. An attempt has been made to identify the defect in the hemophilic blood coagulation mechanism with some of the known components of the blood coagulation reaction. Therefore, the fibrinogen, prothrombin, plasma protease content and the hemophilic clot promoting ability of the 2 plasmas and their derived protein fractions were studied. Also, a comparison was made of the distribution of plasma proteins in normal and hemophilic plasmas as shown by electrophoresis.

\section{METHODS}

One thousand $\mathrm{ml}$. of fresh hemophilic plasma fractionated by the Harvard Physical Chemistry Department, using the same methods they had previously applied to 
normal plasma. The 5 protein fractions so obtained were tested for fibrinogen, prothrombin, enzyme activity after treatment with chloroform, and antihemophilic activity and were compared with 5 similar fractions from normal pooled plasma. All fractions were dissolved as 2 per cent solutions in $\mathbf{0 . 8 5}$ per cent sodium chloride solution, and the $\mathrm{pH}$ adjusted to between 7 and 7.4.

The fibrinogen content was tested by measuring the coagulation time after the addition of $0.1 \mathrm{ml}$. of thrombin $^{2}$ to $0.1 \mathrm{ml}$. of the protein solution. Prothrombin was determined by a modified Quick test (10) using human brain thromboplastin.

Protease activity was determined after plasma or solutions of the plasma protein fractions were activated by shaking 1 minute with $1 / 10$ their volume of chloroform. The enzyme activity was estimated by the addition of an equal volume of 1 per cent casein solution ( $\mathrm{pH} 7.5$ ) and measurement of the non-protein nitrogen produced by enzymatic hydrolysis.

Coagulation times were measured by a modification (11) of the method of Lee and White at $37.5^{\circ} \mathrm{C}$. In vitro estimations of the antihemophilic activity of the various protein fractions were made by the addition of $2 \mathrm{ml}$. of freshly drawn hemophilic blood to $0.1 \mathrm{ml}$. of various dilutions of the test material, and subsequent measurement of the coagulation time.

\section{RESULTS}

In vitro. Table I shows the components of the protein fractions as prepared by the Physical Chemistry Department of the Harvard Medical School. It will be noted that most of the fibrinogen is in Fraction I, and most of the prothrombin in Fraction II + III. Fraction V is almost pure albumin.

TABLE I

Distribution of the plasma proteins in normal fractions*

\begin{tabular}{c|c|c|c|c|c|c}
\hline \hline & $\begin{array}{c}\text { Albu- } \\
\text { min }\end{array}$ & $\begin{array}{c}\alpha \text {-glob- } \\
\text { ulin }\end{array}$ & $\begin{array}{c}\beta \text {-glob- } \\
\text { ulin }\end{array}$ & $\begin{array}{c}\gamma \text {-glob- } \\
\text { ulin }\end{array}$ & $\begin{array}{c}\text { Fibrin- } \\
\text { ogen }\end{array}$ & $\begin{array}{c}\text { Total } \\
\text { protein } \\
\text { per liter } \\
\text { of } \\
\text { plasma }\end{array}$ \\
\hline I & 0.2 & 0.2 & 0.8 & 0.5 & 2.6 & 4.3 \\
II + III & 0.7 & 1.8 & 6.2 & 6.0 & 1.6 & 16.3 \\
IV & 1.0 & 5.4 & 3.1 & 0.2 & & 9.7 \\
V & 29.0 & 0.6 & & & & 29.6 \\
\hline
\end{tabular}

* Adapted from Cohn, E. J., Oncley, J. L., Strong, L. E., Hughes, W. L., and Armstrong, Jr. S. H., The characterization of the protein fractions of human plasma. J. Clin. Invest., 1944, 23, 417.

Table II shows a comparison of the fibrinogen and the prothrombin content of hemophilic and normal plasma and their derived protein fractions. It is seen that the prothrombin and fibrinogen

2 Lederle "Clotting Globulin." content were found to be identical in the 2 plasmas, and similarly distributed in corresponding fractions.

TABLE II

Fibrinogen and prothrombin content of normal and hemophilic plasmas and plasma protein fractions

\begin{tabular}{l|c|c}
\hline \hline & Fibrinogen time & Prothrombin Time \\
\cline { 2 - 3 } Normal: Plasma & 3 seconds & 20 seconds \\
Run 183: Fraction I & 60 seconds & 25 minutes \\
Fraction II+III & 30 minutes & 4 minutes \\
Fraction IV & 0 & 1 minute \\
Fraction IV-3, & 0 & 60 minutes \\
Fraction V & 0 & 0 \\
Hemophilic: Plasma & 3 seconds & 20 seconds \\
Fraction I & 60 seconds & 2 minutes \\
Fraction II+III & 60 minutes & 2 minutes \\
Fraction IV & 0 & 1 minute \\
Fraction IV-3, & 0 & 0 \\
Fraction V & 0 & 0 \\
& &
\end{tabular}

The proteolytic activity of both hemophilic and normal plasma and plasma protein fractions, after treatment with chloroform, was found to be very similar.

Figure 1 shows the percentage increase of nonprotein nitrogen produced in a casein substrate after treatment for 13 days with chloroformactivated plasma and fractions. The non-protein nitrogen was measured almost daily. There is little activity during the first 12 hours, and the slope of elevation of non-protein nitrogen then rises rather steeply, and at 6 days begins to flatten out. There is no significant difference between the hemophilic and normal curves.

Fractions I, II + III, IV-1 contained most of the proteolytic activity, while the production of non-protein nitrogen following the addition of chloroform-treated Fractions IV-3, 4 and V to a casein substrate is minimal and of the same degree as that produced by an isotonic saline control.

The hemophilic clot promoting activity differed markedly between normal and hemophilic plasma and derived fractions, as shown in Tables III and IV. As has been previously shown in this laboratory $(12,13)$ normal Fractions I and II + III are rich in hemophilic clot promoting substance. Similar fractions obtained from hemophilic plasma showed no such activity. The hemophilic fractions II + III and IV-1 had slight activity, which is probably due to the small amounts of thrombin which have been shown to be present in these materials. 


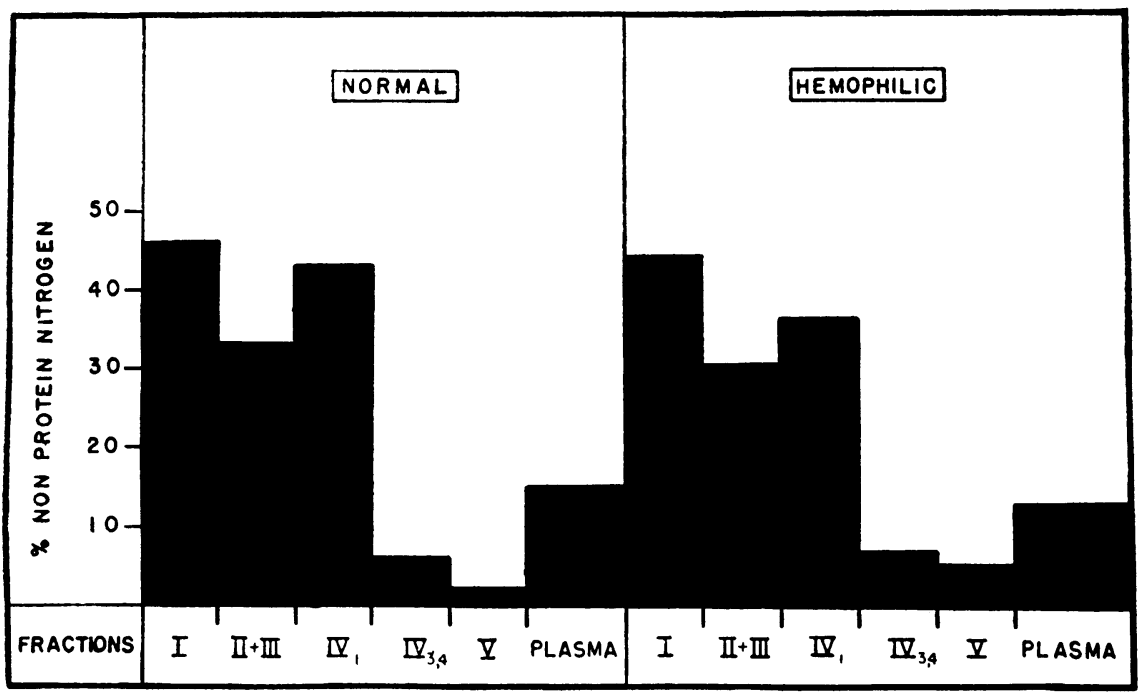

Fig. 1. Comparison of the Percentage of Non-protein Nitrogen Produced in a Casein Substrate by the Proteolytic Action of Chloroform-activated Plasma and Protein Fractions after 13 Days

Electrophoretic analysis of 4 hemophilic plasmas were done for us by Dr. S. Howard Armstrong, Jr., in the department of physical chemistry of the Harvard Medical School. In Table V are shown the mean values compared to the normal obtained from pooled plasma. No significant difference was found between the normal and hemophiliac.

In vivo. Transfusions of $100 \mathrm{ml}$. of compatible blood into hemophilic patients were carried out, using both fresh uncitrated blood injected rapidly intravenously, and citrated blood which had stood at room temperature for 2 hours. Neither of these procedures produced shortening of the recipient hemophiliac's coagulation time.

TABLE III

Antıhemophilic activity of normal and hemophilic plasmas

\begin{tabular}{l|c|c|c}
\hline \multicolumn{2}{c|}{ Normal plasma } & $\begin{array}{c}\text { Hemophilic } \\
\text { blood }\end{array}$ & $\begin{array}{c}\text { Coagulation } \\
\text { time }\end{array}$ \\
\hline dilution & $m l$. & $m l$. & min. \\
0 & 0.1 & 2 & 8 \\
$1-10$ & 0.1 & 2 & $9 \frac{1}{2}$ \\
$1-100$ & 0.1 & 2 & 17 \\
$1-1000$ & 0.1 & 2 & 25 \\
\hline \multicolumn{1}{c|}{ Hemophilic plasma } & & \\
\hline 0 & 0.1 & 2 & 48 \\
$1-10$ & 0.1 & 2 & 48 \\
$1-100$ & 0.1 & 2 & 48 \\
$1-1000$ & 0.1 & & 42 \\
\hline \multicolumn{2}{c|}{ Normal saline } & 2 & \\
\hline
\end{tabular}

TABLE IV

Antihemophilic activity of normal and hemophilic fractions

Normal fractions

$$
\begin{aligned}
& \text { I } \\
& \text { II + III } \\
& \text { IV-1, } \\
& \text { IV-3, } 4 \\
& \text { V }
\end{aligned}
$$

Hemophilic fractions

$$
\begin{aligned}
& \text { I } \\
& \text { II+III } \\
& \text { IV-1 } \\
& \text { IV-3, } 4
\end{aligned}
$$$$
\text { Saline }
$$

Anti-hemophilic activity

$$
\begin{gathered}
+++ \\
++ \\
++ \\
+-
\end{gathered}
$$$$
\begin{gathered}
0 \\
+- \\
+- \\
0 \\
0 \\
0
\end{gathered}
$$

Figure 2 shows a comparison between the injection of $100 \mathrm{ml}$. of fresh uncitrated hemophilic blood, followed in 2 hours by the injection of 100 $\mathrm{ml}$. of fresh uncitrated normal blood. There is a marked shortening of the recipient's coagulation time following the normal blood transfusion, but

TABLE V

Comparison of electrophoretic components of hemophilic and normal plasmas

\begin{tabular}{l|c|c|c|c|c|c}
\hline \hline & $\begin{array}{c}\text { Albu- } \\
\text { mins }\end{array}$ & $\begin{array}{c}\alpha 1 \\
\text { globu- } \\
\text { lins }\end{array}$ & $\begin{array}{c}\alpha 2 \\
\text { globu- } \\
\text { lins }\end{array}$ & $\begin{array}{c}\beta \text { globu- } \\
\text { lins }\end{array}$ & $\begin{array}{c}\text { Fibrin- } \\
\text { ogen }\end{array}$ & $\gamma$ globu- \\
lins
\end{tabular}


this did not happen when the hemophilic blood was administered.

Hemophilic plasma was likewise injected into a hemophilic patient without appreciable change in the coagulation time.

Figure 2 shows a comparison of the effect of intravenous transfusion of equal amounts of hemophilic and normal Fraction 1 into the same hemophilic patient. The shortening of the recipient's coagulation time after injection of normal Fraction 1 is in marked contrast to the insignificant change after injection of hemophilic Fraction 1.

It was not unexpected to find the prothrombin and fibrinogen content of the hemophilic protein fractions to be similar to the corresponding normal fractions. This is a confirmation of the generally accepted fact that the coagulation defect in hemophilia is not due to a deficiency of fibrinogen or prothrombin.

Thrombin is not normally present in the circulating blood, but appears during the blood coagu- lation reaction. In hemophilia, the conversion of prothrombin to thrombin is impaired. This is probably not due to the presence of an anticoagulant, as hemophilic blood or plasma added to normal blood does not prolong the coagulation time of the normal blood. It appears therefore, that the delayed formation of thrombin in hemophilia is due to a deficiency of one or more of the precursors of thrombin. In view of the fact that the coagulation defect in hemophilia is corrected by the addition both in vitro and in vivo of small amounts of fibrinogen, prothrombin and plateletfree plasma (14), and that the prothrombin content of hemophilic plasma is normal, the conclusion seems inescapable that there is a precursor of thrombin other than prothrombin which is deficient in hemophilic plasma.

This substance has been termed "globulin substance" by Taylor (6), "plasma thromboplastin" by Howell (15) and "plasma thromboplastic enzyme" by Ferguson (16). These 3 authors agree that the active substance is derived from plasma,

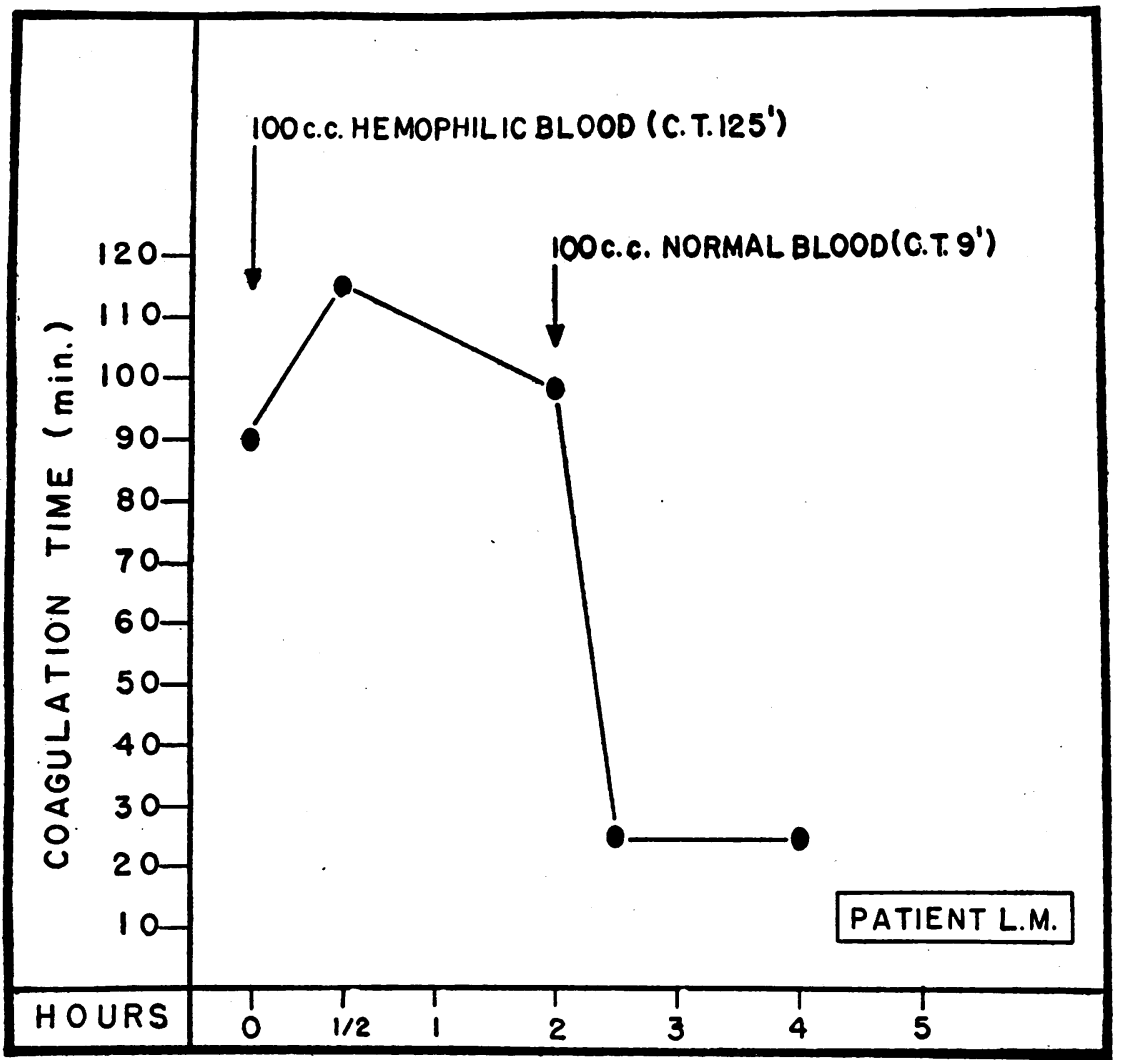

Fig. 2. A Comparison between the Injection into a Hemophilic Patient of Hemophilic and. Normal BLOOD 


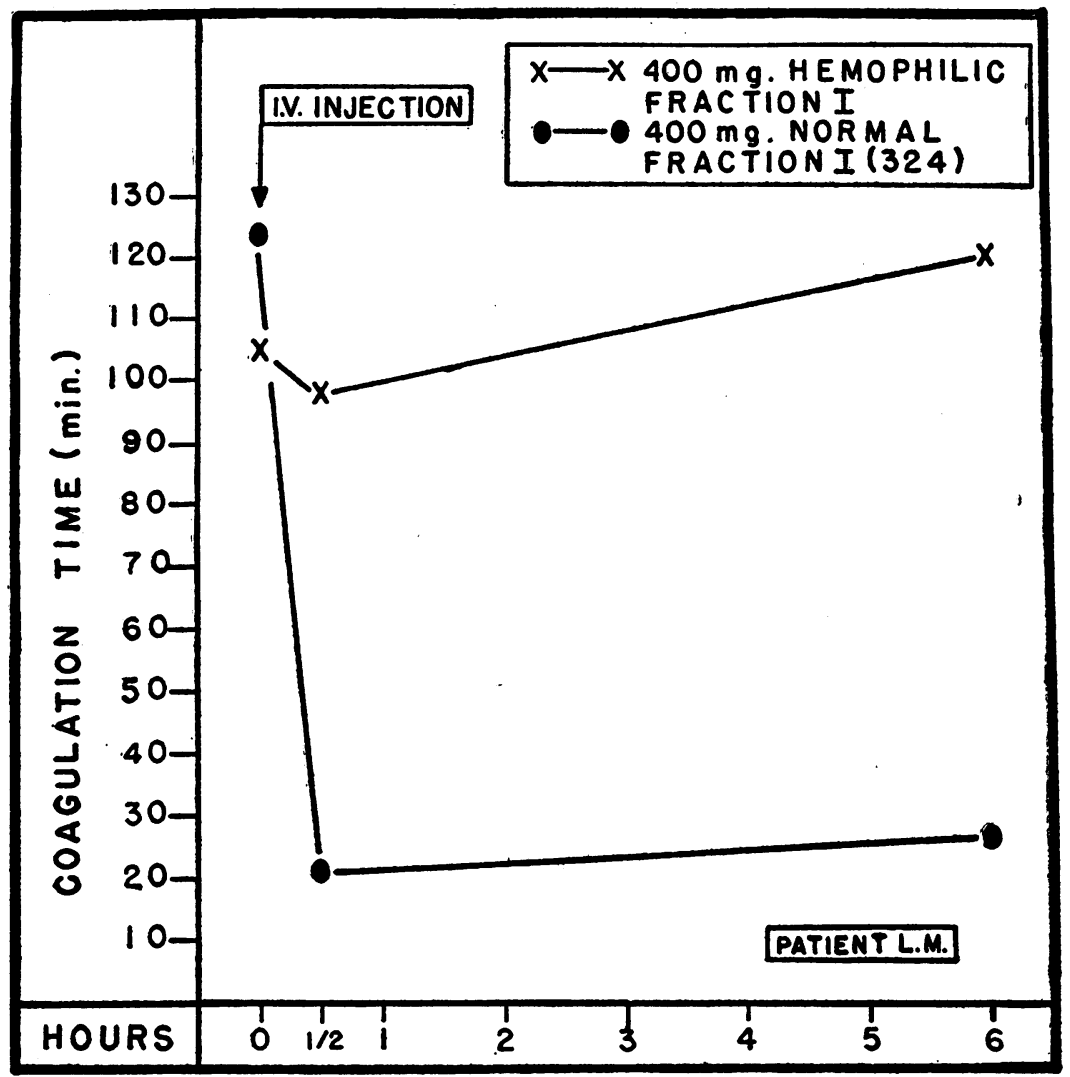

Fig. 3. A Comparison between Intravenous Injections of Equal Amounts of Hemophilic and Normal Fraction I into the Same Hemophilic Patient

but little is known as to its chemical nature. The term "globulin substance" used by Taylor implies that the active material is associated with the globulin fraction of the proteins of plasma, but is not meant to convey the idea that it is a globulin or even a protein. Ferguson has advanced indirect evidence indicating that the proteolytic enzyme and the antihemophilic factor of plasma are identical, but direct proof of this is lacking. Tocantins (17) suggests an antithromboplastic substance present in hemophilic plasma which inhibits the normal thromboplastic action and thus produces defective blood coagulation.

Tagnon, Davidson and Taylor (18) have compared the fibrinolytic activity of chloroform-treated normal and hemophilic plasmas, and observed that the fibrinolytic activity was reduced in hemophilic plasma. The results presented in this paper are in contrast to these in that they show little difference in proteolytic activity between normal and hemophilic póoled plasma, or their corresponding protein fractions. This discrepancy may be due to the difference in technique used in either investigation. The protease activity of the normal and hemophilic fractions seems to be identical, but while the protease activity is paralleled by the presence of antihemophilic activity in the normal plasma protein fractions, there is no such relationship in the hemophilic fraction.

A plasma factor deficient in hemophilia could not be identified with fibrinogen, prothrombin, or the proteolytic enzyme. The deficiency of this factor in hemophilic plasma does not alter the Tiselius diagram. Further attempts are being made to isolate this factor by subfractionation of the active globulin fractions with which it is associated.

\section{CONCLUSIONS}

1. Normal and hemophilic plasmas are similar in detectable protein composition and distribution.

2. The fibrinogen and prothrombin content are identical. 
3. The proteolytic activity of the 2 plasmas, or their corresponding protein fractions after treatment with chloroform, is identical.

4. Normal plasma and normal Fractions, I, II + III and IV-1 contain a substance capable of shortening hemophilic coagulation time. This substance is absent in hemophilic plasma and its corresponding fractions.

\section{BIBLIOGRAPHY}

1. Weil, P. E., L'Hémophilie; pathogénie et sérothérapie. Presse Medicale, 1905, 13, 673.

2. Minot, G. R., and Lee, R. I., The blood platelets in hemophilia. Arch. Int. Med., 1916, 18, 474.

3. Addis, T., The pathogenesis of hereditary hemophilia. J. Path. and Bact., 1911, 15, 427.

4. Feissly, R., Recherches experimentales sur la correction (in vivo) de la coagulation sanguine chez l'hemophile. Actes de la Societe Helvetique des Sciences Naturelles, II partie, 1924, 212.

5. Patek, A. J., Jr., and Stetson, R. P., Hemophilia; abnormal coagulation of blood and its relation to blood platelets. J. Clin. Invest., 1936, 15, 531.

6. Patek, A. J., Jr., and Taylor, F. H. L., Hemophilia; some properties of substance obtained from normal human plasma effective in accelerating coagulation of hemophilic blood. J. Clin. Invest., 1937, 16, 113.

7. Bendien, W. M., and van Creveld, S., On some factors of blood coagulation, especially with regard to the problem of hemophilia. Acta. med. Scandinav., 1939, 99, 12.

8. Pavlovsky, A., and Simonetti, Celia, Determinacion del poder coagulante de la fraccion globulina extraida de plasmas hemofilicos. Anales del instituto de Investigaciones Fisicas Aplicadas a la Patologia Humana, 1944, Ano VI, vol. 6.
9. Cohn, E. J., Unpublished methods.

10. Quick, A. J., Stanley-Brown, M., and Bancroft, F. W., Study of the coagulation defect in hemophilia and in jaundice. Am. J. M. Sc., 1935, 190, 501.

11. Pohle, F. J., and Taylor, F. H. L, The coagulation defect in hemophilia: The effect in hemophilia of intramuscular administration of a globulin substance derived from normal human plasma J. Clin. Invest., 1937, 16, 741.

12. Taylor, F. H. L., Davidson, C. S., Tagnon, H. J., Adams, M. A., MacDonald, A. H., and Minot, George R., Studies in blood coagulation: The coagulation properties of certain globulin fractions of normal human plasma in vitro. J. Clin. Invest., 1945, 24, 698.

13. Minot, George R., Davidson, C. S., Lewis, J. H., Tagnon, H. J., and Taylor, F. H. L., The coagulation defect in hemophilia: The effect, in hemophilia, of the parenteral administration of a fraction of the plasma globulins rich in fibrinogen and antihemophilic activity. J. Clin. Invest., 1945, 24, 704.

14. Lozner, E. L., Kark, R., and Taylor, F. H. L., The coagulation defect in hemophilia. The clot promoting activity in hemophilia of Berkefelded normal human plasma free from fibrinogen and prothrombin. J. Clin. Invest., 1939, 18, 603.

15. Howell, W. H., Hemophilia. Bull. New York Acad. Med., 1939, 15, 3.

16. Ferguson, J. H., The clotting of hemophilic plasma by thromboplastic enzyme. Am. J. Physiol., 1939, 126, 669.

17. Tocantins, L. M., Demonstration of antithromboplastin activity in normal and hemophilic plasmas. Am. J. Physiol., 1943, 139, 265.

18. Tagnon, H. J., Davidson, C. S., and Taylor, F. H. L., The coagulation defect in hemophilia; a comparison of the proteolytic activity of chloroform preparations of hemophilic and normal human plasma. J. Clin. Invest., 1943, 22, 127. 